
Biblical women in early modern literary culture

\section{MANCHESTER 1824}

Manchester University Press 
Victoria Brownlee and Laura Gallagher - 9781526110633 Downloaded from manchesterhive.com at $04 / 26 / 2023$ 01:45:20PM via free access 


\title{
Biblical women in early modern literary culture I550-I700
}

\author{
edited by \\ VICTORIA BROWNLEE \\ and LAURA GALLAGHER
}

Manchester University Press 
Copyright (C) Manchester University Press 2015

While copyright in the volume as a whole is vested in Manchester University Press, copyright in individual chapters belongs to their respective authors, and no chapter may be reproduced wholly or in part without the express permission in writing of both author and publisher.

Published by Manchester University Press.

Published by Manchester University Press

Altrincham Street, Manchester Mi 7JA, UK

www.manchesteruniversitypress.co.uk

British Library Cataloguing-in-Publication Data

A catalogue record for this book is available from the British Library

Library of Congress Cataloging-in-Publication Data applied for

ISBN 978071909155 I hardback

First published 2015

The publisher has no responsibility for the persistence or accuracy of URLs for external or any third-party internet websites referred to in this book, and does not guarantee that any content on such websites is, or will remain, accurate or appropriate.

Typeset in Dante by

Koinonia, Manchester 